\title{
Serialization and Multiplication in Portraiture: Stanisław Ignacy Witkiewicz and Photographic Translations
}

The face is the thing.

Virginia Woolf

In the words of Urszula Czartoryska, the proto-modernist artist and philosopher Stanisław Ignacy Witkiewicz created a "new 'gravitational field"' in photography (Czartoryska 1980: 61). I propose to consider the highly expressive portraits by Witkiewicz (1885-1939) as forms which dramatize something pioneering about the openness of the photographed human face, about the interface of photographic portraits and other forms of expression, such as portrait painting and verbal portraiture, about the meanings of repetition which does not repeat. Caught between indexical, iconic, and symbolic qualities, Witkiewicz's multimedia expositions of the face present a powerful provocation to speculation on intersemiotic translations.

Guided by his father who praised photography for its "arrangements of mutual relations between objects" (Barański 2000: 404), young Witkiewicz enthusiastically traced its overt and covert meanings. As a child he took many photographs which he also catalogued, thus creating a unique register of "photography + documentation" (Krzysztofowicz-Kozakowska 1989: 43). His growing personal archives included series of photographs of roads, landscapes, locomotives, and people. Albums and boxes of photographs were his distinctive space not of Art but of life creativity. Arranged by kind, documentary photographs, theatrical photographs, series of keepsake snapshots, photographs containing reproductions of his paintings, curiosity photographs, constituted a collection which the photographer additionally considered interpretable with respect to diverse qualities and feelings it 
produced. This large ensemble, evoking the landscape of prewar years in Poland, burned when his Warsaw apartment was raided by Nazis in 1939 (Okołowicz 2000: 182). What has survived the war's destruction is a body of about 1500 photographs saved by friends of the artist.

Made available to the public, reproduced in commercial albums and academic publications, these images reveal that Witkacy took a special creative interest in portraits, that his key subject was the human face, his own face and the faces, in particular eyes and lips, of people he knew. To identify his interests and practice, Witkiewicz is said to have used made-up portmanteau words like "the facedesigner", "mugmodeller", and "spiritual facesampler". Towards the end of his life he developed a habit of calling himself "the old portrait prostitute" (Gerould 1993: 24). In basic terms, his portraits evoke figurative possibilities of the human face, of its abundant spurious poses, grimaces, and twitches. Witkiewicz's photographs evoke also extraordinary heterogeneity of the exteriority of the face as a theatrical mask, a camouflage, a perversion; they manifest not only some intimations of subjectivity but also the power of cultural conventions. There are readings that construe some of the portraits as indexes of complex tensions lying somewhere behind, symptoms of a model's disease. Selfportraits of the artist, his "autoWitkacies", however, are determined not only by their highly troubled model, understandable in relation to images of innumerable familial faces, but also in their historical context, as artwork produced in response to "insatiable craving' for novelty" in $20^{\text {th }}$ century art (Gerould 1993: 10). Witkiewicz recognized the potential which portraiture held to traverse the distinctions between public and private, to move towards more fluid and more accidental arrangements. If "the face is also the primary medium for deliberate self-presentation" (qtd. in Freeland 2010: 297), in his self-portraiture Witkiewicz leads us to expect a proliferation of layers of signs and a variety of means to display levels of penetration of these layers. Numerous captions and comments on these self-representations signal over and over again anticipated disintegration and even annihilation of the self.

Witkiewicz's creative use of photography has a lot to do with serialization and multiplication of images; by many decades they anticipate self-portraits and self-dramatizations by such contemporary artists as Cindy Sherman, Egon Schiele, and Bruce Nauman. "Unlike one painting", argues Susan Sontag, "one photograph [...] implies that there will be others" (1979: 166). While photography has contributed to the disparagement of the singularity of the portrait, thanks to artists like Witkiewicz it has also expanded the potential of new significations of plurality of images. His principle of multiplication of photographic 
portraits made up of many views of the same subject, taken at intervals and from diverse points of view, and in diverse conditions runs counter to the revelatory and celebratory traditions of portraiture, counter to what Krauss identifies as the artistic principle of absolute innovation and originality embraced by modernist artists (Krauss 1987: 160-161). Witkiewicz's multiples alert to potentiality of the unexpected emergence of new signs. For instance, we learn in letters from his friends that Witkiewicz "[...] studied systematically human faces, enlarging the photographs to paranormal sizes [...]. Often, such an enlarged likeness revealed characteristic, funny, caricature-like details [...]" (qtd. in Krzysztofowicz-Kozakowska 1989: 44). The challenge such images presented had to do with the out of the ordinary relations formed by serialized photographs, relations introducing dynamic fields of poiesis, of symbolic transformations.

Striving to generate some unity in multiplicity, inspired also by successes of his photographic practice, Witkiewicz serialized photo-based images, also pastel and charcoal portraits. Many of his photographic portraits of friends but also self-portraits were taken against the background of his multiple pastel portraits and drawings. Such densely interconnected arrangements are a complex means of signaling changing motivations behind his work and changing practices of display. Photographs which include sitters as well as their painted portraits, or other painted images hanging on walls of personal interiors, undermine static, mimetic qualities of portraiture. Our attention is directed not to the monumental precision of focus or the mastery of received codes, rather, as in a 1913 photograph captioned "Jadwiga Janczewska in Stanisław Ignacy Witkiewicz's room", we are confronted with a site of (re)production of conflicting personal explorations. The sitter is a vehicle, objectified in a practice linked to art and familial history.

Witkiewicz was primarily a painter and it was the experience that taught him how to approach photography creatively, how to use the camera to make room for buffoonery, irony, and blague. A significant critical attention has been devoted to his large Portrait-Painting Firm, Witkiewicz's famous "large mug-modeling firm". For instance, Stefan Okołowicz stresses the important fact that such an undertaking had no equivalent in $20^{\text {th }}$ century art (2000: 154). What has not been emphasized enough though is how this unprecedented project, operating for fifteen years, with a few thousand portraits to its credit, attracting the attentions of so many paying customers, contributed to the development of a novel way of marketing and distribution of portraiture as a purchasable, reproducible, and replaceable commodity. Witkiewicz, the sole owner 
of the firm, highlighted the importance of the customer's decision in the choice of the "type" of desired portrait (the decision was facilitated with the aid of sample albums produced by the firm). The motto of the firm announced that "The customer must be satisfied. Misunderstandings are ruled out". If the portrait did not suit the customer because of "the degree of likeness" or any other reason it could be rejected (Gerould 1993: 239240). The portraitist's chief focus was faces: "In general, the firm does not pay much attention to the rendering of clothing and accessories" (Gerould 1993: 240). Special arrangements were necessary for full-length portraits, and prices went significantly up if a customer wished to have his hands painted: "every hand costs one third of the price" (Gerould 1993: 240). Affordable to an average customer, though one third more expensive for women, the portraits were made according to terms and regulations published in a 1928 brochure. They were signed with the name Witkiewicz for "straightforward portraits", and Witkacy for his "deformed work" (Gerould 1993: 17). Initially customers could choose five types of portraits, however, Witkiewicz allowed mixing and diversification of the types. The firm sought to bring out the character, the type, the shared features and the shared iconographic motifs like heads captured to look like statues. The types ranged from the most objective ones to those most caricaturelike. Labeled as type A, B, (including most conventional and the most expensive portraits); C, D, and E (reserved for a wide circle of friends, oneiric and mystical, expected one day to become rarities), the portraits were defined and made meaningful in relation to other portraits. For example, defining the type $\mathrm{C}$, Witkiewicz allowed complex supplements like $\mathrm{C}+\mathrm{Co}, \mathrm{C}+\mathrm{H}, \mathrm{C}+\mathrm{Co}+\mathrm{Et}$. These specifications were meant to clarify the characteristics of a sitter but also the conditions of the production. Additionally, because Witkiewicz knew many of the models intimately, he could make multiple series, at times producing "tens of versions of the portrayed model, done in varying moods and with the application of diverse stimulants" (Krzysztofowicz-Kozakowska 1989: 36). The experiments with substances like peyote and heroin helped him render the faces dark, heavy, deformed. Clearly, such portraits departed from any existing conventions in portraiture.

Photographic portraits, however, provided yet more experimental means of self-depiction and presentation of a human presence. Shearer West argues that in early stages of the development of the invention one of the most important reasons for the popularity of photography among portraitists was that "photography appeared to provide a foolproof means of conveying likeness. The conception that a photograph reveals truth initially seemed to offer the model of mimesis required for 
portraiture" (West 2004: 189). West reminds that "the etymology of the term 'portraiture' indicates the genre's association with likeness and mimesis" (ibid.: 21). Thus likeness conceived as a "copy or duplication of external features" (ibid.: 21), is thought of as one of the essentials of the form of portraiture. Especially for artists interested in self-portraiture, and self-promotion, photography made it possible to manage without the mirror (ibid.: 191), to explore freely countless ways for signaling changes in identity, hiding rather than displaying likeness. Witkiewicz's probing orchestrations of experimental exposures which included also cooperation with professional photographers like Janina Kępińska resulted in the creation of an extraordinary archive of faces.

As Czartoryska observes, dating back to 1905, photograph portrait plays for Witkiewicz a double role as a "model of human relationships (between the observed and the observing in which he detected a particularly interesting situation especially when he was both) and a model for the definition of man" (Czartoryska 1980: 56). Photographically-ceased faces in Witkiewicz's portraits seem to evoke what he referred to as "directional tensions" ("Pisma o sztuce"). The " $\mathrm{I}$ " in these portraits is never presented in full body, a finished character, something to be simply understood. The subject is always a fragmented, even decomposed personality, often a lunatic, an unstable partial somebody with an accelerated grimace of disgust and horror, "unfinishable" and unknowing.

In a familiar multiple portrait (dated 1914-1916, taken in St. Petersburg), Witkiewicz appears dressed in a military uniform (he voluntarily joined the Imperial Army in St. Petersburg in 1914). This quintuple, cubist-like portrait - we should add a very popular type of image at the time, shows us reflections of Witkiewicz; the multiplication of uniform brings to mind multiplication of doubles that the WW1 called up as it did call up obscurity, auto-destruction, death, alterity and estrangement. We see the same face, but thanks to mirror reflection every face is different, the face en trio quarts, en face, and back. Janusz Degler interprets these portraits as autobiographical explorations of Witkiewicz's multiple selves: the self of the artist, the painter, the self of the philosopher, the self of the writer, and the self of the photographer (Degler 2009: 14). Clearly, there is no abiding self exposed though; we do not get to see the full face of the sitter; we can only sense its presence concealed somewhere there at the juncture of all these selves, or reflections. At the time of its making this type of image was not considered a portrait but "multi-photography". Yet it must have been sufficiently playful and theatrical to draw Witkiewicz's attention. A form of self-exploration, it seems to gesture beyond the particular identity of 
the artist. The notable military uniform connects this image to a larger cultural and historical context and can be read as a symbol.

Witkiewicz was interested in how the portrait appropriates on the way an "otherness" that in the end reflects or even diffuses the subject. As I will show, especially his indulgent and absurd theatrical games, role playing, thematizing parodying and mocking portraiture uncover and release the strangeness or alterity of "I" as "we".

Witkiewicz's photographic experiments included shortening the focal length by placing a ring made of a water pipe, which allowed him to achieve more than a close up, a kind of a micro-photography of the human face. This technique (introduced around 1912) helped him liberate the image of the face from its contours. Such a tight frame is Witkiewicz's original invention. According to Czartoryska, it is the forerunner of the way the human face became to be framed in film and TV. Witkiewicz himself thought of the resulting images as "wonderful" (Czartoryska 1980: 58). The tight frame seems to allow the face to morph, to lose its completeness, its definition. Such an image seems an effect of perception, not of "just being".

What's worth noticing is the fact that Witkiewicz's experiments came a decade before French surrealists' and American modernists' explorations of portraiture. For example, in order to set off the eyes, Witkiewicz eliminates background, clothes, ears and hair. He uses light in an expressionistic way; dedicating intense attention to the expression of the eyes. They are enlarged, blurry and lit in such a way that we feel their powerful hypnotic appeal. Light glides across the faces producing unique visual effects, not contact. These eyes do not look at the viewer; nothing animates them. In a series of portraits presenting his fiancé, Jadwiga Janczewska, he records unreal, fuzzy facial expressions of a young woman who was to commit suicide; the repeated, multiple framing devises including busy interiors, contours of pictures hanging on walls, different angles from which the dazzling light is introduced deny clarity to her body. She is not accessible. Viewed in a series, the face of the female dissolves, it degrades to become washed away like faces in memory. Similarly to a series of portraits of Witkiewicz's ill father, these photographs depict disappearance of traces of autonomy, of life, of subjectivity.

Contact and intimacy are problematic, if at times impossible to achieve in verbal portraits Witkiewicz produced, for example, in his early autobiographical novel 622 Falls of Bungo. Narrative portraiture is "always a form of prosopopoeia, of 'giving face' to words" believed to be 'literal' (West 2004: 55). In The 622 Downfalls of Bungo or the Demonic 
Woman (1910-1911) Bungo (Witkiewicz) looks at himself as if he were watched and recorded by someone other than himself. He sketches grotesque masks on the face of Bungo the artist, he portrays his friend Duke to reflect his own face, as when he says:

The Duke's face was frankly atrocious. His parched lips were half-open in an imbecilic smile, his eyes, without his glasses, were hazy and had a confused look of criminal desire, mute supplication, and repulsive sorrow. For a split second Bungo looked at him with artistic satisfaction. That face, almost alien to him at that moment, resembled the demonic figures in his drawings. But at almost the same moment he saw everything and something so hideous gripped him that he was suddenly paralyzed with fear. (Gerould 1993: 65)

Writing the novel, Witkiewicz was painting portraits of his friends which bore fictional names as captions. Also to illustrate the characters, Witkiewicz was relying on photography to "show" and "document" these characters to his father. This process of translation was a strategy of self-exploration which appeared throughout his work. It proves that for Witkiewicz the connections between writing and photography were always indissoluble.

Witkiewicz says that his photographic techniques were used to "export the techniques of the psyche of the photographed person" (Gerould 1993: 15). He produced series of psychological portraits which illustrate his key principle based on the assumption that only very many photographs can approximate some idea of a person. Hence we get the principle of serialization in the photographic portraits of his fiancé, of Malinowski, of other friends, and his father. Witkiewicz's father is captured sitting in the same pose, framed partially, he appears in details, his body reduced to the head only or seen as a profile. Vantage points betray the intensity of proximity and distance in the difficult relationship between the sitter and the camera operator.

Inspired by Ernst Kretschmer's explorations of connections between the human physique and inclinations towards psychic diseases; Witkiewicz tried to map a morphopsychological typology. Despite technical developments in photographic resolution, Witkacy discovered that photography could not probe the psyche of the model. He distanced himself from the search for psychic diseases, and continued to explore photography as a tool documenting the visible. He got interested in a different kind of portraiture. In the 1930s, he was staging what he called the theatre of "faces", producing series of looks, of reflexes, mimic inventions, semblances of the face. "Miny" or "grimaces" are body art, multiplications of the variants of his faces. Witkiewicz was convinced 
though that they could be more self-revealing of the mystery of the human self. In a semi-serious text "Manifest (Fest-mani)" he wrote about the necessity of breaking the intolerable boredom of "always being oneself", of hope that "I can imitate anything and thus free myself from the damned identity of individuality" (Gerould 1993: 711).

Witkiewicz's staged paratheatrical scenes are blagues which express what he felt was the "chaos of the wildest contradictions" which defines the inner life (Gerould 1993: 712). Taken with the help of his friend Jozef Glogowski, Grimaces show mere inconclusive possibilities of expression. They do not give us the face but rather deform the face; they are illusions of faces; they emphasize certain surplus, the " $\mathrm{I}$ " and something else, almost as if he were determined to conjure up some performative notions of the self. In the repeated series of "faces", facial expressions recorded by Witkiewicz are made possible as a result of transforming the body where one expression calls for another expression. Coming in series, these images make visible the loss of resemblances and differences. To try to make known things reappear and to produce them over again makes not the truth but the lie apparent. It is clear that there is no ultimate version of the ultimate gesture or face; photography makes this subversive deception clear.

These multiplied and serialized faces both resist and invite invention; such traces of pure potentiality (Markiewicz), they call attention to identity of repetition, of redundancy, the identity of the repeated elements, clearly affirmed repeated gestures. Unlike traditional art where repetition reinforces established ideologies, in avant-garde we deal with art which offers opportunities of autonomy incompatible with the social system. Witkiewicz's serialization and repetition do not stand in opposition to innovation; in Eco's words, such a strategy of ostentatious redundancy, oscillates between the assertive defense or promotion of the face and display of the impossibility of its manifestation.

\section{References}

Barański, Janusz (2000). "Malinowski i Witkacy. Między sztuką życia i prawdą absolutną". Konteksty 1-4: 399-419.

Czartoryska, Urszula (1980). “Laboratorium 'Psychologii Nieeuklidesowej’, czyli o fotografiach Witkacego". Odra 3: 55-61.

Degler, Janusz (2009). Witkacego portret wielokrotny. Warszawa: Państwowy Instytut Wydawniczy. 
Franczak, Ewa, and Stefan Okołowicz (1986). Przeciw nicości. Fotografie Stanistawa Witkiewicza. Kraków: Wydawnictwo Literackie.

Freeland, Cynthia (2010). Portraits and Persons. Oxford: Oxford University Press. Gerould, Daniel (ed.) (trans.) (1993). The Witkiewicz Reader. London: Quartet Books.

Gerould, Daniel, and Jadwiga Kosicka (1983). "Witkacy: An Album of Photos a Bundle of Letters". Performing Arts Journal 7 (3): 59-75.

Janicka, Elżbieta (1997). “O portrecie fotograficznym w aspekcie rury wodociągowej". In: Fotografia: Realność medium. Eds. Alicja Kępińska, Grzegorz Dziamski, and Stefan Wojnecki. Poznań: Akademia Sztuk Pięknych.

Krauss, Rosalind (1987). The Originality of the Avant-garde and Other Modernist Myths. Cambridge, Mass.: Cambridge University Press.

Krzysztofowicz-Kozakowska, Stefania (1989). Firma portretowa Stanisława Ignacego Witkiewicza. Kraków: Wydawnictwo Literackie.

Michałowska, Marianna (2004). Niepewność przedstawienia. Od kamery obskury do wspótczesnej fotografii. Kraków: Rabid.

Okołowicz, Stefan (2000). "Portrety metafizyczne". Konteksty 1-4: 183-197.

Peirce, Charles Sanders (1986). "Letters to Lady Welby". In: Critical Theory Since 1965. Eds. Hazard Adams, Leroy Searle. (639-646). Tallahassee: Florida State University Press.

Potocka, Anna Maria (ed.) (2009). Witkacy. Psychoholizm. Kraków: Bunkier Sztuki. Sontag, Susan (1979). On Photography. London: Allen Lane.

West, Shearer (2004). Portraiture. Oxford: Oxford University Press. 